\title{
DA NECESSIDADE DE PROTEÇÃO PROCESSUAL ESPECIAL AO DIREITO AMBIENTAL
}

FROM THE NEED FOR SPECIAL PROCESS PROTECTION TO ENVIRONMENTAL LAW

Nelson Luiz Pinto ${ }^{1}$

\section{RESUMO}

O objetivo deste artigo é analisar a necessidade de e uma proteção processual especial no direito ambiental, tendo em vista a relevância dos bens jurídicos a serem protegidos. Primeiramente, apresentamos algumas considerações sobre a efetividade da tutela jurisdicional. Em seguida, faremos uma breve análise das diversas espécies de tutelas jurisdicional, com ênfase para tutela mandamental e para a tutela cautelar de urgência. Procuraremos destacar a relevância e a importância do sistema de proteção ao meio ambiente, bem como os mecanismos para proteção do meio ambiente no âmbito direito processual. Por fim, em conclusão, será verificada a necessidade de proteção processual especial no âmbito do direito ambiental, não apenas por força da natureza excepcional dos bens envolvidos e de sua vital importância para toda a humanidade, mas também porque os eventos danosos ao meio ambiente são notadamente irreversíveis, de modo a merecer especial atenção do Estado-Juiz visando a concessão de tutela jurisdicional célere e eficaz para proteção do meio ambiente e, consequentemente, de toda a coletividade.

PALAVRAS-CHAVE: Direito Constitucional - Direito Internacional -Direito Processual - Direito Ambiental - Tutela Jurisdicional

\section{ABSTRACT}

The purpose of this article is to analyze the need for and special procedural protection in environmental law, considering the relevance of legal assets to be protected. First, we present some considerations about the effectiveness of judicial protection. Next, we will make a brief

\footnotetext{
${ }^{1}$ PUC/SP; Universidade Estadual de Rio de Janeiro - UERJ; Universidade Cândido Mendes - UCAM. Brasil. Email: renatapinto@npa.adv.br
} 
analysis of the various types of jurisdictional tutelas, with emphasis on guardianship and guardianship of urgency. We will seek to highlight the relevance and importance of the environmental protection system, as well as the mechanisms for protecting the environment in the procedural law area. Finally, in conclusion, the need for special procedural protection under environmental law will be verified, not only because of the exceptional nature of the goods involved and their vital importance for the whole of humanity, but also because harmful events to the environment are notably irreversible, in order to deserve special attention from the Judge State aiming at the granting of prompt and effective judicial protection for the protection of the environment and, consequently, of the whole community.

KEYWORDS: Constitutional Law - International Law - Procedural Law - Environmental Law Jurisdictional Protection

\section{INTRODUÇÃO}

O presente artigo busca analisar, de maneira geral, os aspectos que circundam o as tutelas jurisdicionais, notadamente sob o prisma da efetividade, da proporcionalidade e da isonomia, com ênfase para a proteção processual especial no âmbito do direito ambiental, em razão da relevância dos bens e valores a serem protegidos.

Os efeitos maléficos da atuação humana para com o meio ambiente, com as notórias consequências catastróficas para as futuras gerações, há muito tem tomando espaço de discussão na comunidade jurídica, não só no Brasil mas em todo o mundo, destacando-se a este respeito a Conferência da ONU realizada em Estocolmo em 1972, cujas diretrizes desencadearam uma séria de inovações legislativas no Brasil.

Considerando o menciona contexto, no primeiro capítulo deste trabalho, nos dedicaremos à questão da efetividade da tutela jurisdicional e seus impactos na proteção dos direitos dos cidadãos, em geral.

Mais adiante, no segundo capítulo, são feitas algumas considerações a respeito das diversas espécies de tutelas jurisdicionais, com ênfase para a tutela de urgência e para a tutela mandamental, ante a importância de ambas para uma efetiva proteção processual ao meio ambiente. 
Em seguida, adentraremos nos conceitos de proporcionalidade e isonomia da tutela jurisdicional, com vistas a introduzir soluções para o aparente conflito de interesses sociais e econômicos, especialmente quando se está diante da proteção ao meio ambiente.

Como ponto principal, procuraremos demonstrar a necessidade de uma proteção processual especial e diferenciada no campo do direito ambiental, destacando sua evolução nas últimas décadas no Brasil.

No quinto capítulo, são analisados os mecanismos processuais dispostos no ordenamento jurídico brasileiro e como devem eles ser interpretados e manejados de forma diferenciada, com vistas a efetivar adequadamente a tutela jurisdicional quando se tratar de proteção processual do Estado ao direito ambiental, considerando principalmente a quase sempre irreversibilidade dos danos causados pelos agentes econômicos.

\section{A EFETIVIDADE DA TUTELA JURISDICIONAL}

A outorga da tutela jurisdicional exige o respeito a determinados princípios fundamentais do Direito Processual Civil, muitos deles alçados à categoria constitucional.

Partindo-se desses princípios, divisa-se uma tutela constitucional do processo, cujo significado e escopo são os de assegurar a conformação dos institutos processuais disciplinados em lei aos postulados que advêm da Constituição Federal.

Sendo, pois, a função dos juízes, a de afirmar a vontade abstrata da lei, tornando-a realidade no caso concreto, ressalta há muito CHIOVENDA, sobre a natureza e finalidade da função jurisdicional, o seguinte:

“[...] parece-nos que o que é característica da função jurisdicional seja a substituição por uma atividade pública de uma atividade privada de outrem. Essa substituição tem lugar de dois modos, referentes a dois estágios do processo, a cognição e a execução" (CHIOVENDA, 1965).

A doutrina de CHIOVENDA está permeada de méritos que serviram, e ainda servem, como proposições fundamentais da ciência processual. Contudo, a crítica mais séria que se poderá fazer a essa doutrina, sem que isto a desmereça, evidentemente, está em que o grande processualista italiano, sob a influência das ideias jurídico-filosóficas predominantes no século XIX, concebia como funções separadas a de legislar e a de aplicar a lei ao caso concreto. 
Assenta-se, pois, seu pensamento, na postulação de que o ordenamento jurídico estatal é um dado prévio, uma situação existente completa e imutável, se não pelo próprio legislador, que se coloca pela norma jurídica para o magistrado, restando a este a exclusiva tarefa de aplicá-la ao caso concreto.

As modernas correntes da filosofia do direito, contudo, procuram mostrar que a atividade de aplicação da lei pelo juiz implica, de certo modo, também uma função criadora de direito, na medida em que o preceito legal abstrato como ele é, em sua formulação genérica, não passa de um projeto de norma reguladora de conduta, projeto que o julgador deve completar na sentença, de modo a concretizá-lo no caso particular submetido a seu julgamento.

Por outro lado, absolutamente de nada adiantaria uma prestação da jurisdição, como atuação concreta da lei por intermédio do órgão do Poder Judiciário competente, se essa atividade carecesse de efetividade, ou seja, se for inócua para aquele que é o titular do direito material invocado e a, aqueles que devem ser tutelados pelo Estado, levando-se em consideração, na formulação da norma judicial concreta, os bens, valores e princípios envolvidos em cada processo.

Essa preocupação já era manifestada por CHIOVENDA no início do século XX, ao asseverar que "o processo deve dar a quem tem um direito tudo aquilo e precisamente aquilo que ele tem o direito de obter" (CHIOVENDA, 1911).

Nessa perspectiva, foi abandonada pela ciência atual do processo a ideia de que a simples prestação jurisdicional, consubstanciada em uma sentença de mérito, seria suficiente para caracterizar a outorga da tutela almejada pela parte. Com efeito, deve-se agregar a esse conceito as noções de eficácia social, de utilidade e de efetividade, como elementos essenciais dessa tutela.

Assim, a exata noção de tutela jurisdicional, como sendo o pronunciamento judicial emanado da autoridade competente, a favor de quem esteja amparado no plano do direito material, somente se completa e se exaure quando possa ser eficaz, útil e efetiva, assegurando-se a sua existência e o seu exercício no plano concreto.

A este respeito, DINAMARCO pondera acerca dos efeitos do decurso de tempo nos processos, que leva o jurisdicionado a aguardar, com angústia, a apreciação de seus pleitos, bem como a entrega efetiva da prestação jurisdicional:

"Um dos grandes desafios enfrentados pelos estudiosos e pelos operadores do processo tem sido ao longo de muitas décadas o da busca de meios capazes de neutralizar os efeitos perversos do tempo sobre os direitos, 
mediante a oferta de meios aptos a proporcionar a tempestividade da tutela jurisdicional - ou seja, a acelerar o curso dos processos em sua caminhada rumo à oferta dessa tutela. Essa preocupação é tanto maior e mais grave quando se sabe que as longas demoras dos processos vêm constituindo o pior dos males de toda a ordem processual, não só neste país mas também naqueles de legislação e organização judiciária mais aprimoradas. $O$ decurso do tempo é muitas vezes o causador do perecimento de direitos ou de insuportáveis angústias pela espera de uma tutela jurisdicional, nascendo daí a imagem do tempo-inimigo, da qual se vale a doutrina há mais de meio século para ilustrar esses desgastes." (DINAMARCO, 2016).

Portanto, a noção de tutela jurisdicional deve encontrar atuação nos fatos, proporcionando a passagem do abstrato para o concreto, do dever ser para o ser, em face casa situação fática e social que se apresentar para o magistrado.

Por esse motivo, deve-se compreender no conceito de tutela jurisdicional, não apenas o resultado declaratório do processo, mas igualmente os meios ordenados e predispostos à obtenção desse mesmo resultado almejado, devendo ser consideradas, neste aspecto, as chamadas tutelas diferenciadas.

Impende dizer, diante disso, que a tutela jurisdicional não é apenas o pronunciamento judicial dado em favor daquele que afirma ser titular de um direito subjetivo ou esteja a defesa de um interesse transindividual, difuso ou coletivo, mas também um pronunciamento que seja efetivo e útil, sob pena ser frustrada a pretensão daqueles que, em face da violação ou ameaça de violação de um direito, buscam guarida e proteção junto ao Poder Judiciário.

Neste ponto, importante citar os ensinamentos de HUMBERTO THEODORO JUNIOR, no tocante à efetividade e celeridade da entrega da prestação jurisdicional, as quais devem ser analisadas sob o prisma da eficiência da administração pública:

"A Constituição estatui, em seu art. 37, quais são os princípios fundamentais que devem gerir a Administração Pública, neles incluindo o da eficiência. A jurisdição, como instrumento de prestação de um serviço público indispensável no Estado de Direito, não fica fora do alcance dos princípios impostos pelo referido art. 37, como é óbvio. Aliás, a regra constitucional prevê, expressamente, sua aplicação à atividade de qualquer dos Poderes Públicos.

O art. 8o do NCPC (LGL\2015\1656) - ao prever que o juiz, no exercício da jurisdição, tem de observar, entre outros, o princípio da eficiência - mantémse fiel ao comando constitucional, e valoriza os compromissos específicos do processo justo com a efetividade da tutela jurisdicional. Indica, portanto, que essa tutela somente será legítima se prestada tempestivamente (em tempo razoável, portanto) e de maneira a proporcionar à parte que faz jus a ela, sempre que possível, aquilo, e exatamente aquilo, que lhe assegura a ordem jurídica material (efetividade da prestação pacificadora da Justiça). Porém, mais do que uma 
tutela efetiva, o processo justo garante uma boa tutela, ou seja, uma tutela eficiente.

Há quem concentre a eficiência do processo na busca da celeridade e da economia processual, resumindo-se na realização da prestação jurisdicional em tempo razoável. Na verdade, contudo, o processo justo idealizado pela Constituição não pode se contentar com a rapidez da prestação jurisdicional. Há metas maiores e que não admitem sacrifício em nome de uma eficiência traduzida em rapidez. Atento ao conjunto principiológico ditado pela ordem constitucional para governar o acesso efetivo à justiça, 'em razão do princípio da eficiência, o procedimento e a atividade jurisdicional hão de ser estruturados para que se construam regras adequadas à solução do caso com efetividade, duração razoável, garantindo-se a isonomia, a segurança, com contraditório e ampla defesa'. O princípio da eficiência, enfim, deve ser analisado, principalmente, sob o enfoque qualitativo, i.e, levando-se em conta a qualidade e a adequação da prestação jurisdicional entregue às partes. O litígio deve ser decidido pelo juiz de forma completa, abrangente, ainda que essa atividade demande maior dispêndio de tempo. Entre a rapidez da decisão e a qualidade da solução apresentada, o juiz deve primar pela segunda, de modo que nunca seja ela sacrificada em prol apenas da dinamicidade do processo." (THEODORO JUNIOR, 2015)

Não à toa, que o princípio da razoável duração do processo, corolário da efetividade, foi inserido originalmente no ordenamento pátrio por meio da Emenda Constitucional n 45/04, a chamada Emenda da "Reforma do Poder Judiciário", que teve como foco justamente a elaboração de medidas que tornassem a entrega da prestação jurisdicional mais célere e eficaz. Tal prisma, inclusive, foi descrito na Exposição de Motivos $n^{\circ}$ 204, subscrita pelo Ministério da Justiça, que assim se manifestou sobre a morosidade do Poder Judiciário:

“Exposição de Motivos/MJ $\mathrm{n}^{\circ}$ 204: Poucos problemas nacionais possuem tanto consenso no tocante aos diagnósticos quanto a questão judiciária. A morosidade dos processos judiciais e a baixa eficácia de suas decisões retardam o desenvolvimento nacional, desestimulam investimentos, propiciam a inadimplência, geram impunidade e solapam a crença dos cidadãos no regime democrático. Em face do gigantesco esforço expendido sobretudo nos últimos dez anos, produziram-se dezenas de documentos sobre a crise do Judiciário brasileiro, acompanhados de notáveis propostas visando ao seu aprimoramento. Os próprios Tribunais e as associações de magistrados têm estado à frente desse processo, com significativas proposições e com muitas iniciativas inovadoras, a demonstrar que não há óbices corporativistas a que mais avanços reais sejam conquistados. O Poder Legislativo não tem se eximido da tarefa de contribuir para um Judiciário melhor, como demonstram a recém-promulgada reforma constitucional (EC no 45/2004) e várias modificações nas leis processuais. A reforma do sistema judicial tornou-se prioridade também para o Poder Executivo, que criou a Secretaria de Reforma do Judiciário no âmbito do Ministério da Justiça, a qual 
tem colaborado na sistematização de propostas e em mudanças administrativas. São essas as premissas que levam os três Poderes do Estado a se reunirem em sessão solene, a fim de subscreverem um Pacto de Estado em favor de um Judiciário mais Rápido e Republicano, consubstanciado nos seguintes compromissos fundamentais (...)." (destacado)

Diante disso, é inexorável a conclusão no sentido de que a eficiência da justiça civil, como valor a ser defendido e preservado, encontra amparo no princípio constitucional da efetividade da tutela jurisdicional e constitui elemento essencial do Estado Democrático de Direito.

Além disso, o processo, como instrumento de realização do direito material e dos valores sociais mais importantes, deve proporcionar esse resultado com rapidez, sob pena de tornar-se inútil e de perecer com o tempo.

Daí decorre a ideia de efetividade como garantia fundamental do processo, a ser extraída dos princípios constitucionais que alicerçam os fundamentos do sistema processual brasileiro. Não basta assegurar, portanto, a existência de mecanismo adequado à solução de controvérsias, se a sociedade não tiver efetivo acesso a ele e, ainda, em tempo hábil.

Em razão disso, a inafastabilidade do processo ou do controle jurisdicional não deve representar apenas uma garantia formal de exercício do direito de ação, absolutamente o contrário é que deve ocorrer, é preciso que seja oferecidas pela lei e deferidas pelo Poder Judiciário as condições reais e eficazes para a utilização desse instrumento, sempre que necessário.

Absolutamente de nada adianta assegurar-se o contraditório, a ampla defesa, o juiz natural e a imparcialidade, se a garantia de acesso ao processo não for efetiva, ou seja, não possibilitar realmente a todos a utilização dos meios suficientes para superar eventuais óbices existentes ao pleno exercício dos direitos postos em juízo. É necessário que garanta, além do acesso, também a saída do judiciário o breve possível, com segurança, justiça, isonomia e efetividade.

Do mesmo modo, também de nada adianta possibilitar o acesso ao Poder Judiciário daqueles considerados hiposuficientes, se estes não tiverem condições plenas para o exercício da postulação ou da defesa em juízo, por carecerem, por exemplo, de recursos financeiros suficientes para sustentar a questão levada à juízo.

Evidentemente, a efetividade da tutela jurisdicional pressupõe, conforme será observado mais adiante, um tratamento igualitário entre as partes que estão litigando, em consonância com o princípio constitucional da isonomia ( $C F$, artigo $5^{\circ}$, caessáput). Igualmente, além da necessária isonomia entre os litigantes, necessária se faz, ainda, a isonomia entre as diversas espécies de direitos postos em juízo, com reconhecimento e respeito às suas desigualmente materiais e sociais. 
Ou seja, tratamento igualitário não significa, necessariamente, tratamento idêntico, até porque, em determinados casos, uma das partes apresenta-se em posição muito mais vantajosa do que a outra, como ocorre, por exemplo, nas relações de consumo, motivo pelo qual é necessária uma intervenção legal ou judicial, a fim de que essa igualdade seja estabelecida ou mantida. Igualmente se dá em relação ao bem da vida objeto do processo, devendo ser observada suas diferenças, importância, essencialidade e relevância social, como ocorre no campo do direito ambiental.

Por esse motivo, as normas jurídicas de direito material e processual possuem uma ratio legis voltada para a tutela de interesses sociais, conferindo ao Poder Judiciário mecanismos que restabeleçam o equilíbrio processual, levando em consideração, dentre outros, o princípio da proporcionalidade.

Ou seja, o direito de agir em juízo, assegurado em sede constitucional, não se exaure em si mesmo, devendo ser examinado em função da tutela pretendida, que deve ser efetiva, real, útil. 0 que interessa para a sociedade e para o destinatário da prestação jurisdicional é a possibilidade concreta de obter proteção ao direito substancial afirmado, e não, ao contrário, ser apenas indenizado em razão das lesões sofridas, particularmente quando essas lesões são pulverizadas em função do grande número de pessoas atingidas, como, por exemplo, o meio ambiente, cuja violação atinge toda a coletividade de cidadãos, quase sempre de forma irreparável.

Essa visão da garantia constitucional do direito de ação leva à conclusão de que o Estado deve colocar à disposição das pessoas os meios adequados para a concreta e integral satisfação dos direitos, em tempo hábil. É necessário proporcionar acesso ao judiciário e recebimento de uma tutela jurisdicional justa, segura e efetiva.

\section{AS DIFERENTES ESPÉCIES DE TUTELA JURISDICIONAL}

Diferentes critérios são utilizados para a classificação dos tipos de tutela jurisdicional prestados pelo Estado, ora considerando apenas a eficácia pretendida para o provimento processual buscado, ora considerando aspectos relevantes sob a ótica do direito material objeto do processo.A classificação tradicional, ou clássica, como a ela se referem os processualistas, é 
composta das tutelas de conhecimento, executiva e cautelar. Na tutela de conhecimento divisamse as tutelas declaratória, constitutiva e condenatória.

Ao lado dessas chamadas tutelas "tradicionais", a doutrina reconhece, cada vez com maior intensidade, a existência das tutelas denominadas de executiva em sentido lato e mandamental.

A tutela executiva em sentido lato, reconhecida pelo nosso sistema processual, determina a satisfação imediata do provimento jurisdicional independente da instauração de novo processo ou do incidente de cumprimento. A referida identificação ocorre a partir da autorização legal para que a ordem se cumpra por mandado, isto é, por ordem do juiz, v. g., nos casos de despejo, reintegração de posse, ação de depósito.

Quanto ao provimento mandamental, ele tem sido identificado na regra do artigo 497 do Código de Processo Civil, e reside no aspecto de que o juiz, em vez de condenar, emitiria uma ordem, cuja inobservância daria ensejo às práticas de sanções tendentes a compelir o devedor ao adimplemento da sua obrigação de fazer, de abster-se de fazer ou, ainda, de entregar alguma coisa.

Com efeito, atribui-se a PONTES DE MIRANDA a introdução da tutela mandamental no direito brasileiro, advinda do direito alemão. CÉLIO HORST WALDRAFF destaca também a grande contribuição do jurista OVÍDIO BATISTA DA SILVA:

\begin{abstract}
"A tutela mandamental é classicamente atribuída a Pontes de Miranda no direito brasileiro, reverenciando a doutrina de Georg Kuttner (Urteilswirkung aussergalb des Zivilprozesses) e seria aquela em que o objetivo principal faz derivar uma ordem do juízo de fazer ou não fazer, de acordo com o sentido da pretensão deduzida.

Em relação a tal definição, obviamente o clássico exemplo é o mandado de segurança, muito embora a perspicácia pontiana identifique uma longa série de exemplos, tais como o habeas corpus, as ações possessórias, o interdito proibitório, o arresto, o sequestro, a busca e apreensão, etc.

Quem fez consolidar a receptividade da tutela mandamental no Direito Pátrio foi, na verdade, Ovídio Batista da Silva, que a estendeu de forma mais indiscriminada para os casos em que se postula 'que o juiz emita uma ordem a ser observada pelo demandado'."
\end{abstract}

Para HUMBERTO THEODORO JUNIOR, na tutela mandamental o juiz emite comando impositivo de certa conduta, cujo descumprimento enseja responsabilização penal:

"O magistrado emite decisões de caráter mandamental, em que não apenas se reconhece a obrigação de realizar certa prestação, mas se dispõe, como ordem de autoridade competente, o comando impositivo de certa conduta. Assim, o seu descumprimento equivale à desobediência ou resistência à ordem legal de autoridade pública (crimes capitulados nos arts. 329 e 330 do Código Penal)." 
A tutela cautelar, por seu turno, tem por objetivo garantir a subsistência de um determinado bem ou direito. Tem por objetivo garantir o objeto do processo de conhecimento em curso ou a ser oportunamente instaurado, enquanto as partes litigantes debatem sobre qual delas é a efetiva titular desse bem.

Até a edição da Lei n. 8.952/94, que introduziu modificações no $\mathrm{CPC} / 73$, revogado pelo novo e atual Código de Processo Civil de 2015, as ações cautelares eram utilizadas indiscriminadamente, não apenas para garantir o resultado útil da demanda principal já aforada ou em vias de sê-lo (cautelar incidente ou cautelar preparatória), mas também como meio de satisfação do resultado prático, que somente seria alcançado com a tutela definitiva, via de regra transitada em julgado, daí surgindo a controvertida questão das ações cautelares de natureza satisfativa. A antecipação de tutela, introduzida em nosso sistema pela referida Lei 8.952/94 e constante do antigo art. 273 do CPC /73 revogado, veio resolver essa questão, propiciando o adiantamento dos efeitos práticos da sentença que, anteriormente, somente poderiam ser deferidos após a verificação da formação da coisa julgada material.

O instituto da tutela provisória, quer de natureza cautelar, para garantia a futura eficácia de uma tutela principal definitiva, quer antecipatória de efeitos dessa tutela principal, vem previsto agora no Código de Processo Civil em seus artigos 294 e seguintes, possuindo origens que remontam à lei n. 4.717, de 29 de junho de 1965 - lei da ação popular - e na lei n. 7.347, de 24 de julho de 1985 - lei da ação civil pública.

Essa tutela diferenciada pode ser deferida quer em razão da urgência na obtenção do resultado prático postulado pela parte, e que somente seria alcançado na sentença; quer em função da evidência ou incontrovérsia do direito em litigio; quer em função do abuso do exercício do direito de defesa da parte contrária, e destina-se ora à preservação do bem da vida que busca proteger na ação principal, quer à própria satisfação total ou parcial da pretensão deduzida em juízo, no plano do direito material.

Ademais, mesmo que não houvesse expressa previsão legal no sentido de ser possível a concessão de tutela provisória, quer no âmbito cautelar, quer no âmbito da antecipação de tutela, ainda assim, poder-se-ia cogitar a outorga de provimento jurisdicional equivalente, em função das regras pertinentes à inafastabilidade do poder judiciário quanto à apreciação de lesão ou ameaça de direito ( $\mathrm{CF}$, artigo $5^{\circ}$, inciso XXXV) e à garantia do exercício constitucional de petição, nele incluído o exercício do direito de ação (CF, artigo $5^{\circ}$, inciso XXXIV, letra "a"), invocando-se, inclusive, os princípios constitucionais da isonomia, assim entendido como o de paridade de armas para que 
haja igualdade processual e, ainda, o princípio da proporcionalidade, na medida em que não seria razoável sacrificar o direito daquele que tem razão, apenas e tão somente para se prestigiar o formalismo processual, além, também, da garantia constitucional à razoável duração do processo.

A garantia constitucional do direito de ação, portanto, não está limitada às tutelas definitivas e satisfativas. A tutela cautelar e as chamadas tutelas diferenciadas, merecendo destaque a antecipação de tutela, estão incluídas no âmbito de proteção que a Constituição Federal defere ao direito de ação que, em última análise, é direito de acesso às garantias do devido processo legal ou devido processo constitucional. Hoje o Código de Processual nomeia genericamente esse tipo de tutela diferenciada de Tutela Provisória, dela tratando nos Livro V do CPC, arts. 294 e seguintes.

Evidentemente, a efetividade da tutela jurisdicional, como garantia constitucional de todas as pessoas, impõe a admissibilidade da tutela cautelar e da tutela antecipada também contra a Administração Pública, naquelas situações em que haja risco de dano irreparável ao direito pleiteado. Não fosse assim, sucumbiria o particular diante do Poder Público, ainda que, ao final, seu direito viesse a ser reconhecido.

\section{OS PRINCÍPIOS DA ISONOMIA E DA PROPORCIONALIDADE DA TUTELA JURISDICIONAL}

As discussões travadas em torno do princípio da isonomia têm ocupado lugar de destaque entre os filósofos do direito, os processualistas, os constitucionalistas, enfim, entre os juristas que se preocupam não apenas com o direito em seu aspecto formal, mas também e principalmente em seu aspecto de Justiça.

Durante muito tempo foi corrente a acepção ditada por ARISTÓTELES no sentido de que isonomia seria tratar igualmente os iguais e desigualmente os desiguais, com a qual, de modo geral, concordavam os juristas sem, contudo, se aperceberem que haviam apenas transferido para outro patamar o grau da discussão, sem resolver a questão de se saber, efetivamente, o que seria isonomia.

Isto porque é necessário identificar as pessoas que seriam consideradas iguais, daquelas que seriam consideradas desiguais para, a partir daí, outorgar-lhes tratamento diferente.

Ademais, tanto aqueles que estariam encartados numa posição de igualdade, como aqueles encartados numa posição de desigualdade, possuiriam entre si peculiaridades que os 
tornariam diferentes uns dos outros, motivo pelo qual é pragmaticamente impossível dar-Ihes um tratamento igualitário ou diferenciado, sem que, adotando uma ou outra posição, houvesse o risco de se causar prejuízos a uns ou a outros decorrentes de uma injusta discriminação. Enfim, quem são os iguais e quem são os desiguais?

Uma solução para essa questão é encontrada na Constituição Federal vigente, observada em Cartas anteriores, que determina: "todos são iguais perante a lei (...)", locução a respeito da qual já havia se manifestado com aguda percepção FRANCISCO CAMPOS:

“[...] malgrado a infelicidade da redação, tem como principal destinatário o legislador, pois de nada adiantaria uma aplicação igual do direito a pessoas, coisas ou fatos que vieram arbitrariamente desequilibrados na lei - sem dúvida o mandamento constitucional tornar-se-ia inócuo.

[...] assim, não poderá subsistir qualquer dúvida quanto ao destinatário da cláusula constitucional da igualdade perante a lei. O seu destinatário é, precisamente, o legislador e, em consequência, a legislação; por mais discricionários que possam ser os critérios da política legislativa, encontra no princípio da igualdade a primeira e mais fundamental de suas limitações" (CAMPOS, 1956).

No mesmo sentido, pondera o eminente filosofo do direito HANS KELSEN, a respeito da questão da isonomia, que:

"[...] a igualdade dos sujeitos na ordenação jurídica, garantida pela Constituição, não significa que estes devam ser tratados de maneira idêntica nas normas e em particular nas leis expedidas com base na Constituição. A igualdade assim entendida não é concebível: seria absurdo impor a todos os indivíduos exatamente as mesmas obrigações ou lhes conferir exatamente os mesmos direitos sem fazer distinção entre eles, como, por exemplo, entre crianças e adultos, indivíduos mentalmente sadios e alienados, homens e mulheres" (KELSEN, 1992).

Acrescenta CELSO ANTÔNIO BANDEIRA DE MELLO que "o princípio da igualdade interdita tratamento desuniforme às pessoas":

"[...] o princípio da igualdade interdita tratamento desuniforme às pessoas. Sem embargo, consoante se observou, o propósito da lei, sua função precípua, reside exata e precisamente em dispensar tratamentos desiguais. Isto é, as normas legais nada mais fazem que discriminar situações à moda que as pessoas compreendidas em uma ou outras vêm a ser colhidas por regimes diferentes. Donde a algumas são deferidos determinados direitos e obrigações que não assistem a outras, por abrigadas em diversa categoria, regulada por diferente plexo de obrigações e direitos. Exemplificando, cabe observar que às sociedades comerciais guardam, por lei, prerrogativas e deveres diferentes dos que pertinem às sociedades civis; aos maiores é dispensado tratamento inequiparável àquele outorgado aos menores; aos advogados se deferem certos direitos e encargos distintos dos que calham aos economistas ou aos médicos, também diferenciados entre si no que concerne às respectivas faculdades e deveres" (BANDEIRA DE MELLO, 1998). 
Conclui-se, diante disso, que somente a lei pode apresentar elementos válidos de discriminação entre as pessoas, reciprocamente consideradas, bem como em relação às coisas e aos fatos juridicamente relevantes.

Deve-se, entretanto, observar, que o princípio da isonomia deve ser considerado não apenas pelo legislador, no momento da elaboração da norma jurídica, mas também e principalmente pelo Poder Judiciário, que tem a função fundamental de interpretar a norma jurídica e aplicá-la, de acordo com a finalidade social a que se destina.

É preciso, ainda, considerar que o legislador, ao editar uma lei reguladora de condutas humanas, o faz sempre em atenção a uma finalidade específica, mesmo que esta não esteja previamente fixada na Constituição, porém nunca contrária a ela. O fim pretendido pela lei tem de ser obtido por um processo de interpretação no momento em que ela é questionada e aplicada.

Sob esse enfoque, o problema da igualdade na lei é solucionado pelo princípio da proporcionalidade que, segundo SUZANA DE TOLEDO BARROS:

“[...] foi cunhado como forma de limitação do poder de polícia, no âmbito administrativo, para coibir medidas excessivamente gravosas aos direitos dos cidadãos (....). Tem por conteúdo os subprincípios da adequação, necessidade e proporcionalidade em sentido estrito. Entendido como parâmetro a balizar a conduta do legislador quando estejam em causa limitações a direitos fundamentais, a adequação traduz a exigência de que os meios adotados sejam apropriados à consecução dos objetivos pretendidos; o pressuposto da necessidade é que a medida restritiva seja indispensável à conservação do próprio ou de outro direito fundamental e que não possa ser substituída por outra igualmente eficaz, mas menos gravosa; pela proporcionalidade em sentido estrito, pondera-se a carga de restrição em função dos resultados, de maneira a garantir-se uma equânime distribuição de ônus" (BARROS, 1996).

Diante do princípio da proporcionalidade, extraído da Constituição Federal dos artigos $1^{\circ}$, inciso III; $5^{\circ}$, caput, e incisos II, XXXV e LIV, e seus $\$ \S 1^{\circ}$ e $2^{\circ}$; e 60 , $\S 4$, inciso IV, correlato dos princípios da isonomia e da reserva legal; para a verificação do respeito de uma lei ou decisão judicial ao postulado da isonomia, estas devem ser analisadas nos seus aspectos intrínsecos, em consonância com a mens legis.

Desta forma, são passíveis de reavaliação as valorações efetuadas pela lei, analisadas em consonância com a Constituição Federal, sendo que esta conclusão não autoriza uma outra, qual seja, a de que o juiz possa substituir os valores legais pelos seus próprios valores.

Com efeito, constata-se o respeito, ou não, aos princípios da isonomia e da proporcionalidade, quando se analisa a decisão judicial confrontando-a com os aspectos fáticos da 
causa, com a qualificação jurídica que lhes foi dada e com a importância e relevância social do objeto do processo, em outras palavras, se foi correto o procedimento de subsunção dos fatos à norma jurídica aplicável, ou que deveria ser aplicada ao caso concreto, analisando-se todos os seus aspectos subjetivos e objetivos.

Havendo conflito aparente de normas, na medida em que é extremamente raro o conflito real (antinomia de segundo grau), é preciso definir qual delas deve prevalecer para ser aplicada ao caso concreto, sendo que essa definição será obtida mediante a aplicação dos princípios da proporcionalidade e da isonomia.

Este procedimento é imprescindível em relação àquelas hipóteses em que dois interesses juridicamente tutelados, mas conflitantes entre si, são colocados um diante do outro, sendo que apenas um deles poderá ser prestigiado pelo Poder Judiciário, circunstância que implicará, evidentemente, no sacrifício do outro interesse.

Ante o exposto, importa saber, neste caso, qual interesse deve prevalecer em detrimento do outro, que acabará sendo desprestigiado e, para tanto, não é admissível dar ao caso uma solução aleatória ou, pior ainda, uma solução que acabe protegendo o interesse que não deveria sê-lo.

Encerradas tais ponderações a respeito da tutela jurisdicional, sua efetividade, suas espécies, bem como sua prestação sob o prisma da isonomia e da proporcionalidade, passemos agora a analisar a sua importância para a tutela do meio ambiente, traçando breves comentários acerca da necessária proteção processual do direito ambiental.

\section{A PROTEÇÃO LEGISLATIVA AO MEIO AMBIENTE}

A humanidade, especialmente nos tempos modernos, vem utilizando as fontes existentes no meio ambiente como se fossem inesgotáveis. A degradação ambiental é evidente e preocupa estudiosos a respeito da própria sobrevivência das gerações futuras. Como já dito anteriormente, o poder econômico já atuou na sociedade de modo desenfreado e sem preocupações com o meio ambiente.

Neste diapasão, a Constituição Federal de 1988 se preocupou com a tutela do meio ambiente, notadamente no "Capítulo VI- Do meio ambiente", em seu artigo 225, o qual dispõe que: "Todos têm direito ao meio ambiente ecologicamente equilibrado, bem de uso comum do povo 
e essencial à sadia qualidade de vida, impondo-se ao Poder Público e à coletividade o dever de defendê-lo e preservá-lo para as presentes e futuras gerações".

Vale destacar que o referido Capítulo da Carta Magna sofreu positiva e forte influência da Declaração de Meio Ambiente, proposta em 1972, na Conferência das Nações Unidas em Estocolmo, que assim dispõe em seu Item 2.:

“2. A proteção e o melhoramento do meio ambiente humano é uma questão fundamental que afeta o bem-estar dos povos e o desenvolvimento econômico do mundo inteiro, um desejo urgente dos povos de todo o mundo e um dever de todos os governos."

É importante destacar que antes mesmo da promulgação da nova ordem constitucional em 1988, já havia preocupação do legislador brasileiro a respeito da proteção ao meio ambiente. Nesse sentido, entrou em vigor em 31 de agosto de 1981 a Lei Federal n 6.938/81, chamada de Lei da Política Nacional do Meio Ambiente.

Por meio do artigo $2^{\circ}$ da referida Lei da Política Nacional do Meio Ambiente, é possível verificar que o objetivo da novel legislação era propiciar a preservação, melhoria e recuperação da qualidade ambiental:

"Art. 2‥ A Política Nacional do Meio Ambiente tem por objetivo a preservação, melhoria e recuperação da qualidade ambiental propícia à vida, visando assegurar, no País, condições ao desenvolvimento socioeconômico, aos interesses da segurança nacional e à proteção da dignidade da vida humana, atendidos os seguintes princípios: [...]."

Neste contexto, JOSÉ RENATO NALINI, ao analisar a evolução do direito ambiental após 20 anos de promulgação da Carta Magna, destacou o papel dos agentes do Estado, notadamente dos magistrados, acerca da proteção ao meio ambiente:

"[...] o desafio do direito ambiental tão bem contemplado na Carta Política de 1988 é de formar juízes corajosos, com destemor suficiente para o enfrentamento de temas candentes e que não se esgotam com o proferir de uma simples decisão, posto que os frutos de um julgamento errado em matéria ambiental serão sentidos no decorrer da historia e talvez constitua empecilho a que a humanidade se prolongue nesta aventura terrena por outros séculos vindouros.

[...] O direito ambiental abre área inimaginável para o juiz moderno. Mais do que um solucionador de conflitos interindividuais, é ele um administrador de situação controvertida. É um construtor da cidadania, um impulsionador da democracia participativa e estimulador do crescimento da dignidade humana até a plenitude possível [...] A sentença é também uma lição. Queira ou não o juiz educa (...). Disposto a educar a comunidade, enquanto encaminha soluções para lides ambientais, poderá o juiz conscientizá-la da tarefa de tutelar o patrimônio natural (...). Dispõe cada juiz brasileiro de uma eficiente cátedra para disseminar conhecimentos sobre a biodiversidade, sobre a 
estratégia da proteção ambiental, sobre suas dimensões emergentes de caráter geoeconômico e geopolítico. Depende exclusivamente da atenção e interesse conferido a cada lide ambiental conscientizar a cidadania da importância da sustentabilidade, em cujo conceito reside o tema da equidade, tão caro aos juízes" (NALINI, 2009).

Fato é que se fez necessária a criação de uma doutrina de direito ambiental, a fim de atingir os ditames da Conferência de Estocolmo, da Constituição Federal de 1988 e da própria Lei da Política Nacional do Meio Ambiente.

Não havia proteção jurisdicional adequada ao meio ambiente, o que passou a ser uma consideração moderna do direito. A este respeito, JÔNATAS LUIZ MOREIRA DE PAULA, dissertando sobre a necessidade de se desenvolver "um" direito processual ambiental, assim pontuou:

"Neste compasso, observa-se a necessidade do desenvolvimento de "um" Direito Processual Ambiental, que leve em conta a aplicação dos institutos processuais especificadamente focados para a proteção ambiental.

Acredita-se que, assim agindo, estará a Ciência Processual contribuindo para a otimização e racionalização da atividade jurisdicional para a realização do Direito Ambiental. Essa contribuição se mostra necessária no presente momento porquanto são pouquíssimas as varas especializadas em questões ambientais - geralmente na Justiça Federal e em algumas poucas subseções judiciárias." (MOREIRA DE PAULA, 2008)

Mais adiante, o mesmo autor pontifica que "a melhor maneira de operacionalizar essa conduta jurisdicional é instituir um princípio-matriz que orienta todo o desenvolvimento da relação processual em demandas ambientais". Tal princípio, nas palavras do mencionado doutrinador é o "Princípio da Máxima Proteção Jurisdicional do Meio Ambiente", que assim pode ser conceituado:

"A Máxima Proteção Jurisdicional do Meio Ambiente consiste num conjunto de técnicas processuais destinadas a assegurar o desenvolvimento válido da relação processual apta a permitir o reconhecimento da existência de uma poluição ou degradação ambiental 1 e assim permitir a concessão da tutela jurisdicional apta e específica para eliminar a ilicitude ou dano ambiental provocado pelo poluidor. 2

Esse princípio possui a árdua tarefa de, simultaneamente, permitir a inserção de técnicas processuais que instrumentalizem a proteção jurisdicional do meio ambiente, sem que se abra mão de condições de validade do processo, a fim de conquistar a devida efetividade processual.

O papel do Princípio da Máxima Proteção Jurisdicional do Meio Ambiente é o de constituir um padrão cultural jurídico a regulamentar o início, o desenvolvimento e a efetivação da tutela jurisdicional em temas que envolvem a proteção ambiental.

Assim, o princípio em tela, cumpre função semelhante ao do Devido Processo Legal, nas vezes em que este se permite protagonizar o papel de fonte do direito processual no Brasil. Contudo, restringe-se a Máxima Proteção Jurisdicional às denominadas demandas ambientais, a ponto de não alcançar a amplitude genérica do devido processo legal." (MOREIRA DE PAULA, 2008) 
Diante das considerações acima, não restam dúvidas acerca da necessária proteção processual especial do meio ambiente, com a criação de doutrina da ciência jurídica, bem como e, principalmente, mecanismos processuais aptos a efetivar tal tutela protetiva.

Concluída a necessidade de proteção processual ao direito ambiental, adiante analisaremos os mencionados mecanismos processuais aptos a efetivar a tutela do direito ambiental.

\section{OS MECANISMOS PROCESSUAIS EXISTENTES PARA EFETIVA PROTEÇÃO AO MEIO AMBIENTE}

O Código de Processo Civil, para refletir o princípio constitucional da isonomia e, ainda, prestar-se efetivamente à sua finalidade, qual seja a de ser instrumento efetivo e eficaz para a prestação da tutela jurisdicional, teve que sofrer uma série de modificações e, a despeito disso, foi necessário editar uma série de normas para amparar direitos que não teriam condições de ser satisfatoriamente garantidos, caso fossem utilizadas, única e exclusivamente, as regras originariamente contidas nesse diploma, marcadamente individualista.

Com efeito, o Código de Processo Civil veda expressamente o ingresso em juízo por aqueles que não tenham legitimidade ou interesse para litigar, segundo a diç̧ão de seus artigos 17 e 18. Em outras palavras, se não houver uma correspondência entre o direito material invocado e aqueles que o invocam em juízo e, ainda, se a tutela almejada (entenda-se ação utilizada) não for adequada para a finalidade postulada, a consequência jurídica será a extinção da demanda sem a apreciação do mérito.

Esse dispositivo, reflexo da feição estritamente individualista do nosso sistema processual de 1973, deixou desamparada a tutela daqueles direitos chamados de metaindividuais, posto que de interesse geral, mas que, muitas vezes, ficavam sem a necessária proteção judicial, por não se saber quem teria legitimidade para defendê-los em juízo, ou mesmo sendo identificados os titulares do direito subjetivo, legitimados para propor a demanda, estes não teriam condições de postular a defesa dos seus direitos, porque o processo civil não comportaria a participação de grandes quantidades de sujeitos em um ou ambos os polos da demanda ou, ainda, porque o valor econômico do bem da vida discutido desautoriza o ingresso em juízo individualmente. 
Este último aspecto acaba sendo de extrema relevância porque, muitas vezes, os detentores do poder econômico, como regra, acabam abusando dos seus direitos, na certeza de que as pessoas atingidas absolutamente nada farão, em função do diminuto valor do prejuízo considerando-se cada situação individual, sem observar o impacto em toda a coletividade. Entretanto, somados esses valores, aferidos em relação a milhares ou milhões de pessoas, atingirse-ão cifras espantosas, revertidas em proveito de uns poucos, em detrimento de uma imensa maioria ou, até, de toda a sociedade.

Com a finalidade de suprir a lacuna do sistema, pertinente à defesa dos interesses difusos, coletivos e mesmo dos individuais homogêneos, foi editada a lei n. 7.347, de 24 de julho de 1985, denominada de lei da ação civil pública, com o objetivo de disciplinar a ação civil pública de responsabilidade por danos causados ao meio ambiente, ao consumidor, a bens e direitos de valor artístico, estético, histórico e paisagístico, assim como a qualquer outro interesse difuso ou coletivo, merecendo destaque a defesa da ordem econômica, concedendo legitimidade extraordinária às pessoas mencionadas no seu artigo $5^{\circ}$, para propor a demanda.

Neste contexto, trata-se dos chamados direitos coletivos, bem como dos direitos difusos, como bem ensina RAQUEL FERNANDES PERRINI:

\footnotetext{
"Nesta categoria de direitos, tomada como gênero, temos como espécies os direitos coletivos e os direitos difusos.

O direito coletivo singulariza-se na medida em que se pode determinar sua incidência a uma certa classe ou categoria, sendo seus titulares passíveis de identificação.

A segunda nota caracterizadora do direito coletivo é o fato de não poder ser fruído individualmente, com exclusividade, vale dizer, um dos integrantes da classe poderá desfrutar, individualmente, do direito; todavia, isso não exclui que os demais integrantes da mesma classe dele usufruam em igual medida. No que pertine à segunda espécie, os direitos difusos, mister que se destaquem seus traços característicos: indeterminação dos indivíduos, indisponibilidade e indivisibilidade.

Em contraste com os direitos coletivos, o direito difuso é pertencente a toda coletividade, sendo impossível precisar-se o exato beneficiário e os limites de sua fruição residindo aqui a tônica desta classe de direitos.

Justamente por não haver um titular identificável, os direitos difusos são indisponíveis. A disponibilidade exige que seu titular seja conhecido para que possa livremente dispor do direito em questão." (PERRINI, 1995)
}

A Constituição Federal, por seu turno, sensível à necessidade de outorgar legitimação para pessoas e instituições voltadas para a defesa dos interesses coletivos, concedeu legitimação extraordinária para as entidades associativas, quando expressamente autorizadas, para representar seus associados ou filiados nos âmbitos judicial e extrajudicial (CF, artigo $5^{\circ}$, inciso XXI) 
e, ainda, a possibilidade de impetrarem mandado de segurança coletivo (CF, artigo $5^{\circ}$, inciso LXX, letras "a" e "b").

Ainda na Carta Magna destaca-se a ação popular ambiental, prevista no art. 5ㅇ, inciso LXXIII, da Constituição Federal, nos termos seguintes:

$$
\begin{aligned}
& \text { "Qualquer cidadão é parte legítima para propor ação popular, que vise anular } \\
& \text { ato lesivo ao patrimônio público ou de entidade que o Estado participe, à } \\
& \text { moralidade administrativa, ao meio ambiente e ao patrimônio histórico e } \\
& \text { cultural, ficando o autor, salvo comprovada má-fé, isento de custas judiciais } \\
& \text { e do ônus da sucumbência". }
\end{aligned}
$$

Releva destacar, que figuram entre os legitimados para a propositura de ação coletiva, com o objetivo de defender os interesses coletivos da sociedade e, particularmente, de proteção ao meio ambiente, o Ministério Público Federal e Estadual, as associações constituídas para essa finalidade e, ainda, as organizações sindicais. Sobre o tema, confira-se o destaque de NELSON NERY JR. a respeito da legitimação do Ministério Público em matéria de direitos coletivos e difusos:

"Tenta-se justificar a legitimação do Ministério Público, por exemplo, como
extraordinária identificando-a com o fenômeno da substituição processual.
Na verdade, o problema não deve ser entendido segundo as regras de
legitimação para a causa, com as inconvenientes vinculações com a
titularidade do direito material invocado em juízo, mas sim à luz do que na
Alemanha se denomina de legitimação autônoma para a condução do
processo (selbtändige Prazeßführungs befugnis), instituto destinado a fazer
valer em juízo os direitos difusos, sem que se tenha de recorrer aos
mecanismos de direito material para explicar referida legitimação. Aliás, não
é de hoje que se aponta na doutrina a inadequação de vincular-se a noção de
legitimidade ordinária para a causa com a afirmação da titularidade do direito
material" (NERY JR., 1992) Vale destacar, para os fins deste artigo, que ação civil pública em matéria ambiental, já estava disposta antes da promulgação da atual Constituição Federal, a saber, na Lei da Política Nacional do Meio Ambiente (Lei 6.938/1981, art. 14, § 19).

Por oportuno, destaca-se também a figura do Inquérito Civil, importante mecanismo préprocessual de proteção ao meio ambiente. Conforme salienta PAULO AFFONSO LEME MACHADO, com o inquérito civil tornou-se possível a investigação do dano e a justa causa para a propositura da ação.

1-Explicitamente visa proteger o meio ambiente, o consumidor e os bens e interesses de valor artístico, estético, histórico, paisagístico e turístico. Interesses difusos e coletivos, como os rotulou a Constituição Federal (art129, III). 
2-A proteção desses interesses e bens far-se-á através de três vias: compromisso da obrigação de fazer, cumprimento da obrigação de não fazer e condenação em dinheiro.

3-A ação da Lei 7.347 abriu as portas do Poder Judiciário às associações que defendem os bens e interesses apontados no item 1. No plano da legitimação foi uma extraordinária transformação.

4-A ação civil pública consagrou um uma instituição - o Ministério Público valorizando seu papel de autor em prol dos interesses difusos e coletivos. 0 Ministério Público saiu do exclusivismo das funções de atuar no campo criminal e da tarefa de fiscal da lei no terreno cível, para nesta esfera passar a exercer o mister de magnitude social.

5-Inova, por fim, essa ação civil no sentido de criar um fundo em que os recursos não advêm do Poder Executivo, mas das condenações judiciais, visando a recomposição dos bens e interesses lesados. Não se trata nessa ação de ressarcir as vítimas pessoais da agressão ambiental, mas de recuperar ou tentar recompor os bens e interesses no seu aspecto supraindividual".

(MACHADO, 2006).

Por fim, ressaltam-se novos instrumentos processuais que vêm sendo utilizados pelos legitimados na tutela coletiva do meio ambiente. A este respeito, ANTONIO SOUZA PRUDENTE menciona a utilização das tutelas de urgência, bem como do incidente de assunção de competência na sistemática do Código de Processo Civil Vigente:

“Nesse contexto processual de tutelas de urgência, há de ver-se que o juiz do terceiro milênio está autorizado pela consciência da cidadania plena e pela ordem jurídica justa a decidir, com total independência, em juízo sumário, com base na verossimilhança das alegações e probabilidades da vontade da lei, já não mais aceitando a condição passiva de locutor impotente e amordaçado pela norma legal, como assim o quis Montesquieu, no passado, e assim o querem, no presente, os condutores da globalização econômica e do capitalismo financeiro e colonialista, no mercado internacional. Estamos vivendo, hoje, sem dúvida, na plenitude do poder geral de cautela do juiz, que de há muito rompera as mordaças da doutrina liberal, para garantir o retorno do cidadão, neste novo século, capaz de reedificar o mundo pela consciência dos homens, no exercício de uma comunhão difusa de sentimentos e de solidariedade, que se ilumina na inteligência criativa e serviente à aventura da vida, no processo de construção de uma democracia plenamente participativa, na defesa oportuna e inadiável do meio ambiente ecologicamente equilibrado, como bem de uso comum de todos e essencial à sadia qualidade de vida das presentes e futuras gerações ( CF, art. 225, caput).

[...]

De ver-se, assim, a título de exemplo, que a maioria expressiva de demandas judiciais de natureza ambiental, em busca de tutelas jurisdicionais de interesses difusos transfronteiriços e intergeracionais, que aportam perante a 5. e 6. a Turmas, componentes da 3. a Seção de nosso TRF-1. - Reg., com jurisdição sobre os maiores biomas do território nacional, na abrangência espacial de catorze unidades da Federação, enquadra-se no espectro normativo do art. 947 do novo CPC, por envolver relevante questão de direito, com grande repercussão social, sem repetição em múltiplos 
processos, tais como as ações civis públicas promovidas pelo Ministério Público Federal, em face das agressões ambientais dos complexos hidrelétricos faraônicos, na Amazônia Legal, como se revelam no âmbito espacial das Usinas Hidrelétricas de Belo Monte e Teles Pires, dentre outras, sem viabilidade econômica e sustentabilidade ambiental, encontrando tais Usinas, no contexto político e abusivamente agressor das "suspensões de segurança", sem os pressupostos legais necessários perante o Judiciário, o aval liberatório das inúmeras agressões e irregularidades nocivas ao meio ambiente ecologicamente equilibrado." (PRUDENTE, 2017).

Assim, com o advento da formação jurídica os direito difusos, consequência inevitável da rebelião das massas, como anteviu Oretega y Gasset em La rebelión de las massas, ou da multiplicação dos direitos, como diz Bobbio em $A$ era dos direitos ou, ainda, da massificação social a que alude Cappelletti em Processo, ideologias, sociedade, que escapam de qualquer definição do ortodoxo sistema público em contraste com o privado, porquanto existe um abismo entre eles, não já mais que falar na possibilidade de se usar o ortodoxo sistema liberal individualista do Código de Processo Civil e normas afins para dirimir os conflitos de massa.

Dessa forma, a jurisdição civil, sob esse aspecto, apresenta-nos dois sistemas de tutela processual: um destinado às lides individuais, cujo instrumento adequado e idôneo é o Código de Processo Civil, e um outro voltado para a tutela coletiva, eu se cale da aplicação da Lei da Ação Civil Pública e do Código de Defesa do Consumidor.

Ante o exposto, verifica-se que ao longo das últimas décadas foram introduzidos na legislação pátria diversos mecanismos de ordem processual, a fim de que a tutela do meio ambiente seja prestada à sociedade de forma célere e eficaz. A partir desta conclusão, traçaremos adiante breves comentários acerca da necessária proteção processual do direito ambiental.

\section{A NECESSÁRIA PROTEÇÃO PROCESSUAL ESPECIAL NO DIREITO AMBIENTAL}

Considerando tudo o quanto já exposto, cumpre destacar que a efetivação da tutela jurisdicional, quando se fala em proteção ao direito ambiental, merece especial atenção, notadamente sob os prismas da isonomia e da proporcionalidade tratados anteriormente, eis que o titular do direito em questão é na verdade não só um cidadão ou uma determinada coletividade, mas sim, em última análise, toda a sociedade.

A defesa do meio ambiente, em razão da natureza do bem rtutelado, que, como sabemos é difuso, e conforme determina o art. 19 da Lei da Ação Civil Pública, receberá tratamento direto e 
primário das normas processuais previstas na jurisdição coletiva (CDC e LACP) e somente de forma secundária ou subsidiária deverão ser aplicados o Código de Processo Civil e os demais diplomas.

Neste contexto, é importante que a legislação do meio ambiente, especialmente por meio dos citados mecanismos processuais, tenha por escopo facilitar a concessão de uma tutela efetiva de proteção ao meio ambiente, privilegiando os órgãos e entidades que atuam como legitimados extraordinários em face daqueles agentes econômicos causadores dos danos ambientais.

A este respeito, como enfatizado no tópico anterior, tanto a Lei Da Ação Civil Pública como a Lei da Política Nacional do Meio Ambiente possuem mecanismos que permitem a concessão útil e eficaz da tutela jurisdicional almejada pelo substituto processual, quer seja ele o representante do Ministério Público, quer seja ele associação.

Cabe ressaltar, desde logo, que o artigo $4^{\circ}$ da lei da ação civil pública contém uma peculiaridade, qual seja, a tutela nele prevista não é apenas preventiva, mas pode conter um comando, uma determinação para um não fazer, para uma abstenção ou, ao contrário, um comando determinativo de um fazer, com o objetivo de assegurar a eficácia da tutela deferida em função dessa lei ou da Lei da Política Nacional do Meio Ambiente.

Estas considerações são necessárias para dizer que em determinadas situações o dano é simplesmente irreparável, particularmente quando envolve tutela destinada a amparar interesses do meio ambiente que, acaso não deferida quando a postularem, importará em absoluta irreversibilidade para estes do dano que se objetivou evitar.

Destaque-se que a primeira justificativa para o surgimento da tutela do meio ambiente, está justamente assentada no reconhecimento de que o meio ambiente é defendido necessariamente pelos órgãos e entidades, sendo que é a todo momento violado pelos agentes econômicos.

Desta forma, sendo o meio ambiente vulnerável na acepção jurídica (ou seja, de necessária proteção especial, visto que os titulares são na verdade o conjunto da sociedade), bem como na acepção social (porquanto exposto em tempo integral à degradação), sua tutela em juízo deverá receber tratamento diferenciado nas ações em que figure como parte um representante de seus interesses, isto com o objetivo de ser garantida a isonomia, o equilíbrio processual.

Tanto isto é verdade que a lei da ação civil pública e a Lei da Política Nacional do Meio Ambiente, sob o pálio da Constituição Federal, apresentam uma série de mecanismos utilizados para a tutela dos interesses ambientais em juízo, tais como a inversão do ônus da prova, a 
legitimação concorrente para a propositura de ações coletivas, a antecipação de tutela, a relativização dos efeitos da coisa julgada etc. Tudo isto para garantir o resultado útil e efetivo das demandas nas quais estejam sendo discutidos interesses do meio ambiente.

Entretanto, como visto cima, além das regras processuais próprias para proteção dos direitos metaindividuais, previstas nos diplomas especiais acima citados, aplica-se subsidiariamente nas demandas que envolvem esses direitos diferenciado o Código de Processo Civil, cujas normas são de concepção individualista, para proteção de direitos subjetivos.

Neste passo é que nos parece essencial destacar que, na aplicação supletiva das regras do CPC em demandas que envolvam a proteção do meio ambiente, compete ao Julgador analisar, interpretar e aplicar as regras processuais incorporado do mesmo espírito em que o legislador, impulsionado pela sociedade, tratou da proteção especial legislativa ao meio ambiente, com máxima atenção para a rápida, completa e eficaz satisfação desses direitos, com efetividade, utilizando-se, até mesmo de oficio, de todos os instrumentos processuais que a lei coloca à sua disposição para esse mister, mesmo em detrimento de direito individuais e interesses econômicos.

A antecipação de tutela apresenta-se, neste aspecto, não apenas como um meio para assegurar o resultado efetivo e satisfatório da prestação jurisdicional, mas também como forma de assegurar o equilíbrio, a igualdade processual, a identidade de armas e de poderes, visando propiciar um verdadeiro contraditório, sem que uma das partes se veja impossibilitada de litigar, assegurando o resultado do processo em razão da desproporcionalidade de condições e de poderes entre os litigantes, em decorrência, principalmente, de pressões econômicas e de ameaças, verdadeira coação do litigante "mais forte" sobre o "mais fraco".

Nesse sentido, SANTIAGO DANTAS já advertia para o problema da igualdade na criação da lei, asseverando que:

"[...] quanto mais progridem e se organizam as coletividades, maior é o grau de diferenciação a que atinge seu sistema legislativo. A lei raramente colhe no mesmo comando todos os indivíduos, quase sempre atende a diferenças de sexo, profissão, de atividade, de situação econômica, de posição jurídica, de direito anterior; raramente regula do mesmo modo a situação de todos os bens, quase sempre os distingue conforme a natureza, a utilidade, a raridade, a intensidade da valia que ofereceu a todos; raramente qualifica de um modo único as múltiplas ocorrências de um mesmo fato, quase sempre os distingue conforme as circunstâncias em que se produzem, ou conforme a repercussão que têm no interesse geral. Todas essas situações, inspiradas no agrupamento natural e racional dos indivíduos e dos fatos, são essenciais ao processo legislativo, e não ferem o princípio da igualdade. Servem, porém, para indicar a necessidade de uma construção teórica, que permita distinguir 
as leis arbitrárias das leis conforme o direito, e eleve até esta alta triagem a tarefa do órgão máximo do Poder Judiciário" (DANTAS, 1948).

Quanto aos valores a serem considerados para essa distinção, releva destacar que a Constituição Federal declara que a ordem econômica é fundada na "valorização do trabalho humano e na livre iniciativa" e "tem por fim assegurar a todos existência digna, conforme os ditames da justiça social" observados os princípios da soberania nacional; da propriedade privada; da função social da propriedade; da livre concorrência; da defesa do consumidor; da defesa do meio ambiente; da redução das desigualdades regionais e sociais, dentre outros mencionados no artigo 170 .

Isto significa que a Constituição Federal consagra uma economia de mercado, de natureza capitalista, pois a iniciativa privada é um princípio básico da ordem capitalista. Em segundo lugar significa que, apesar de adotar o regime capitalista, a ordem econômica dá prioridade aos valores do trabalho humano sobre os demais valores da economia de mercado, enfatizando a necessidade de se atribuir uma função social à propriedade.

Ressalte-se, ademais, que o respeito à livre concorrência encontra limite na defesa do consumidor e principalmente do meio ambiente, bem como na redução das desigualdades regionais e na busca do pleno emprego.

Estes aspectos todos evidenciam que há uma desigualdade entre aqueles que são detentores do poder econômico, titulares dos meios de produção e de fornecimento de bens e serviços de um lado, e a coletividade social afetada pela exploração danosa ao meio ambiente.

Por este motivo, não por outro, que a própria Constituição Federal elegeu como um de seus princípios basilares, nos arts. $5^{\circ}$, LXXIII e 225, a defesa do meio ambiente.

Ademais, Constituição Federal procura assegurar a todos a existência digna, conforme os ditames da justiça social. Esta tarefa, evidentemente, não é fácil num sistema de base capitalista, ainda mais quando possui contornos essencialmente individualistas.

Desta forma, apesar de consagrar a livre iniciativa como categoria constitucional, esta não deve prevalecer em detrimento do direito ambiental, igualmente tutelados pela Constituição Federal.

Diante disso, havendo colidência entre os interesses do direito ambiental - e consequentemente de toda a coletividade - e o dos detentores dos meios de produção de bens e serviços, evidentemente que deverão os primeiros ser tutelados pelo juiz, no processo, de forma especial. 
Em relação à antecipação de tutela, esta sempre poderá acarretar risco de irreversibilidade no plano empírico. Esse risco, entretanto, pode decorrer tanto do deferimento, como do indeferimento da tutela antecipada. De qualquer forma, quer seja deferida, quer seja indeferida a antecipação de tutela, o juiz ou tribunal estará beneficiando uma das partes da demanda em detrimento da outra. Nestes casos, atuará o princípio da proporcionalidade, devendo o juiz ou o tribunal evitar o risco ou o prejuízo maior, protegendo aquela parte da demanda processual considerada mais fraca, cujo interesse prepondera em relação ao da outra parte, por ter menor possibilidade de suportar o risco da irreversibilidade.

Neste plano, vale repisar que um dano ambiental é praticamente irreversível e não poderá ser substituído por pecúnia, ou seja, ser convertido em perdas e danos. Em outras palavras, a área de proteção desmatada, a plantação queimada, a emissão de poluentes na atmosfera, não poderá ser substituída e retornar ao status quo ante' por meio de uma indenização, tornando ainda mais relevante a atuação imediata e eficaz do Estado-Juiz na proteção do direito ambiental.

Podemos, assim, concluir que o poder Judiciário, aparelhado com leis que viabilizam uma rápida e eficaz proteção ao meio ambiente, ou em relação a bens e interesses relevantes para a sociedade, assim considerada em seu conjunto, não deve vacilar em outorgar a tutela jurisdicional almejada, maxime quando se colocam em confronto os interesses de grupos econômicos voltados apenas e tão somente para a aferição de lucro, decorrente de formação de cartéis e restrição da livre concorrência, de um lado, e os interesses coletivos de outro.

\section{CONCLUSÃO}

Ante as considerações acima postas, é inexorável a conclusão no sentido de que a eficiência da justiça civil, como valor a ser defendido e preservado, encontra amparo no princípio constitucional da efetividade da tutela jurisdicional e constitui elemento essencial do Estado Democrático de Direito.

Essa visão da garantia constitucional da ação também leva à conclusão de que o Estado deve colocar à disposição das pessoas os meios adequados para a concreta e integral satisfação dos direitos. 
Neste diapasão, a garantia constitucional do direito de ação, portanto, não está limitada às tutelas definitivas e satisfativas. A tutela cautelar e as chamadas tutelas diferenciadas, merecendo destaque a antecipação de tutela, estão incluídas no âmbito de proteção que a Constituição Federal defere ao direito de ação que, em última análise, é direito de acesso às garantias do devido processo legal ou devido processo constitucional.

Havendo conflito aparente de normas, na medida em que é extremamente raro o conflito real (antinomia de segundo grau), é preciso definir qual delas deve prevalecer para ser aplicada ao caso concreto, sendo que essa definição será obtida mediante a aplicação dos princípios da proporcionalidade e da isonomia.

Este procedimento é imprescindível em relação àquelas hipóteses em que dois interesses juridicamente tutelados, mas conflitantes entre si, são colocados um diante do outro, sendo que apenas um deles poderá ser prestigiado pelo Poder Judiciário, circunstância que implicará, evidentemente, no sacrifício do outro interesse.

Importa saber, neste caso, qual interesse deve prevalecer em detrimento do outro, que acabará sendo desprestigiado e, para tanto, não é admissível dar ao caso uma solução aleatória ou, pior ainda, uma solução que acabe protegendo o interesse que não deveria sê-lo.

Neste contexto, não restam dúvidas acerca da necessária proteção processual especial do meio ambiente, especialmente no momento de aplicação das normas gerais do Código de Processo Civil às demandas ambientais, com a utilização dos mecanismos processuais aptos a efetivar tal tutela protetiva.

Ressaltam-se novos instrumentos processuais que vêm sendo utilizados pelos legitimados na tutela coletiva do meio ambiente, como, por exemplo, a utilização das tutelas de urgência, notadamente em caráter antecedente, bem como do incidente de assunção de competência na sistemática do Código de Processo Civil Vigente.

É importante que a legislação do meio ambiente, especialmente por meio dos mecanismos processuais prórprios, tenha por escopo facilitar a concessão de uma tutela efetiva de proteção ao meio ambiente, privilegiando os órgãos e entidades que atuam como legitimados extraordinários em face daqueles agentes econômicos causadores dos danos ambientais.

Isso porque, em determinadas situações o dano é simplesmente irreparável, particularmente quando envolve tutela destinada a amparar interesses do meio ambiente que, acaso não deferida quando a postularem, importará em absoluta irreversibilidade para estes do 
dano que se objetivou evitar. Em outras palavras, um dano ambiental é praticamente irreversível e não poderá ser substituído por pecúnia, ou seja, ser convertido em perdas e danos.

Portanto, em conclusão, é de extrema relevância e merece especial atenção a atuação imediata e eficaz do Estado-Juiz na proteção do direito ambiental, sobretudo quando o Código de Processo Civil estiver sendo aplicado subsidiariamente pelo julgador, pois suas normas não foram na origem elaboradas em nome e tendo em vistas esses interesses maiores e mais relevantes para a sociedade.

\section{REFERÊNCIAS BIBLIOGRÁFICAS}

BANDEIRA DE MELLO, Celso Antônio. Curso de Direito Administrativo. 12 e 13, 3a ed. 5a triagem. São Paulo: Malheiros, 1998.

BARROS, Suzana de Toledo. O Princípio da Proporcionalidade e o Controle de Constitucionalidade. 1a ed. Brasília: Brasília Jurídica, 1996.

BUENO, Cassio Scarpinella. Novo código de Processo Civil anotado / Cassio Scarpinella Bueno - 2 ed. Ver., atual. E ampl. - São Paulo: Saraiva, 2016.

CAMPOS, Francisco. Direito Constitucional, Rio de Janeiro: Freitas Bastos, 1956, p. 16.

CARNEIRO, Paulo Cezar Pinheiro. Breves Comentários ao Novo Código de Processo Civil, Teresa Arruda Alvim (et al), coordenadores, São Paulo: Revista dos Tribunais, 2015.

CHIOVENDA, Giuseppe. Principi di diritto processuale civile, §2º , reimp., Padova, 1965, p. 296.

CHIOVENDA, Giuseppe. Dell'azione nascente dal contratto preliminare. Rivista del diritto commerciale, v.9, 1911, p. 1

DANTAS, San Tiago. Igualdade perante a lei e due process of law: uma contribuição ao estudo da limitação constitucional do poder legislativo, RF 116/364. Rio de Janeiro: Forense, 1948

DINAMARCO, Candido Rangel. Teoria geral do novo processo civil. São Paulo: Malheiros, 2016, p. 55-56.

FIORILLO, Celso Antonio Pacheco. Direito Ambiental Brasileiro. São Paulo: Malheiros, 2000, p. 217219

KELSEN, Hans. Teoria pura do direito, Coimbra: Armênio Amadado, 1992, p. 190.

MACHADO, Paulo Affonso Leme. Direito Ambiental Brasileiro. 14. ed. São Paulo: Malheiros, 2006, 1094.

MILARÉ. Édis. A ação civil pública após 20 anos: efetividade e desafios. São Paulo: Revista dos Tribunais, 2005, p. 639.

MITIDIERO, Daniel. Breves Comentários ao Novo Código de Processo Civil,/ Teresa Arruda Alvim (et al), coordenadores, São Paulo: Revista dos Tribunais, 2015.

MOREIRA DE PAULA, Jônatas Luiz. Doutrinas Essenciais de Direito Ambiental | vol. 4 | p. 1277 1302 | Mar / 2011 DTR $2008 \backslash 709$. 
NALINI, José Renato. A evolução do direito ambiental nos 20 anos de vigência da Constituição Federal de 1988. In: MORAIS, Alexandre de (coord.). Os 20 anos da Constituição da República Federativa do Brasil. São Paulo: Atlas, 2009. p. 306.

NERY JUNIOR, Nelson. Princípios do Processo Civil na Constituição Federal (LGL\1988\3), S. Paulo, RT, 1992, p. 108.

PERRINI, Raquel Fernandes. A ação popular como instrumento de defesa ambiental. Doutrinas Essenciais de Direito Ambiental | vol. 4 | p. 937 - 974 | Mar / 2011 DTR\1995\154.

PINTO, NELSON LUIZ. Processo em Perspectiva, em homenagem a José Carlos Barbosa Moreira, São Paulo: Revista dos Tribunais, 2013.

PRUDENTE, Antônio Souza. Tutela processual de urgência em defesa do meio ambiente sustentável, no contexto evolutivo da jurisprudência constitucional. Revista dos Tribunais. RCP vol. 3 (junho-novembro 2016) Processo Civil Comparado.

THEODORO JÚNIOR, Humberto. Curso de Direito Processual Civil - Teoria geral do direito processual civil, processo de conhecimento e procedimento comum - vol. I, 56⿳亠 ed. rev., atual. e ampl. Rio de Janeiro: Forense, 2015, p. 421.

WALDRAFF, Célio Horst. Os poderes mandamentais do juiz no novo CPC e a superação da multa do art. 475-J do CPC/1973. In. Revista eletrônica [do] Tribunal Regional do Trabalho da 9a Região: Vol. 5, n. 50 (maio 2016). Disponível em <https://hdl.handle.net/20.500.12178/94739>. Acesso em 3.2.2019.

Trabalho enviado em 28 de agostp de 2019

Aceito em 20 de abril de 2020 